\title{
Local Government Finance in Ghana: Disbursement and Utilisation of the MPs share of the District Assemblies Common Fund
}

Nana Nimo Appiah-Agyekum

Assistant Lecturer

University of Ghana

\section{Nana Yaw Boachie Danquah}

Senior Lecturer

University of Ghana

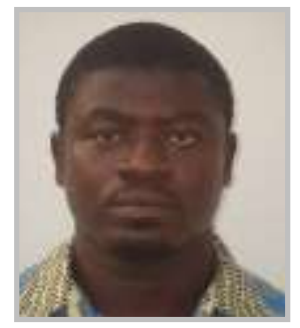

\section{Emmanuel Kojo Sakyi}

Associate Prof \& Head of Department University of Ghana
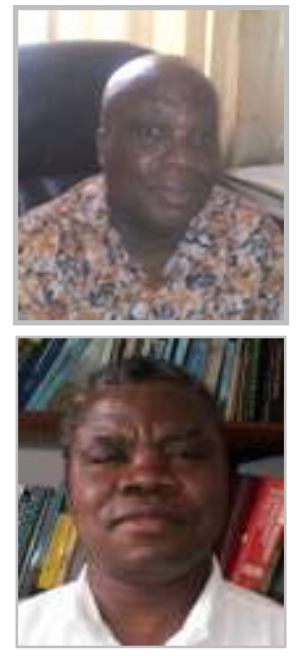

\begin{abstract}
The establishment of the District Assembly Common Fund (DACF) in 1993 and concomitant percentage set aside for Members of Parliament (MPs) in 2004 aims to support local governments and legislators in pro-poor development activities in their communities and constituencies. In spite of the importance of the MPs' share of the District Assemblies Common Fund (MPsCF) in financing local level development in Ghana, very little is known about monitoring systems and procedures on the disbursement and utilization of the funds. The study therefore assessed qualitative data derived from interviews with officials from selected Local Government Authorities (LGAs) as well as other key stakeholders in the disbursement and utilization of the fund. The study findings point to the absence of legislative instrument on the management of the MPsCF. Further, monitoring of the fund was a responsibility shared by the LGAs and other external stakeholders. Finally, the effectiveness of monitoring the disbursement and utilization of the MPSCF was strongly influenced by the relationship between the Chief Executive of the Local Government Authority (LGCE) and MPs in the local government area.
\end{abstract}

Key Words: Disbursement, Utilization, Members of Parliament, District Assemblies Common Fund, Ghana 


\section{Introduction}

Ghana has a multiparty Parliament which has a deliberative, legislative, resource allocation, monitoring and lobbying role. Constitutionally, Parliament has the role to scrutinize public policy especially executive poverty-related policies to ensure equity in program distribution and accountability, and to exert oversight over the proper and judicious administration of development programs.

Parliament is required to ratify executive decisions and choices when it comes to bilateral and multilateral donor loans earmarked for socio-economic development and poverty reduction activities. Whilst there are competing values and interests among the parties in Parliament, there appears to be broad bipartisan consensus over pro-poor policymaking and implementation. This notwithstanding, different parties in parliament have different policy options and strategies in the fight against poverty. Essentially as politicians, they pursue policies that meet popular demands. With the majority of Ghanaians being poor, parliamentarians tend to be sensitive to popular sentiments and often articulate pro-poor messages from the grassroots. Thus, in their bid to win votes, one may say that parliamentarians a lightning rod for poverty-related problems that affect their constituents.

Whilst Parliament has been articulating pro-poor policy positions, the quality of Parliament's involvement in pro-poor policy-making and implementation over the years has been very low. First, the Ghanaian Parliament has not been particularly good at initiating policies. It has yet to demonstrate any capacity to drive the legislative agenda or exert its independence from the Executive in policy legislation. In addition, Parliament is constrained by a number of factors: constitutional, legal, procedural, organisational and material. The partial fusion of the Legislature and the Executive in the 1992 Constitution undermines institutional separation of powers and parliamentary independence while reinforcing executive manipulation and dominance.

Constitutional provisions giving the Executive the exclusive right to initiate bills with financial implications and limiting Parliament to reducing proposed budget appropriations severely limits Parliament's control over the public purse. Parliament as a political and policy institution lacks offices, logistics and the capacity to research, monitor and audit Executive-driven pro-poor policies, and the quality of parliamentary policymaking is severely impaired by weaknesses in information gathering and analysis. Moreover, Parliament has a poor record of proactively soliciting information from independent sources and experts to challenge executive and bureaucratic information, and the role of Parliament in the budget-making process has been sidelined. The involvement of Parliament and its Finance and sector committees in the preparation and review of the annual budget is marginal, Parliamentary debates over the estimates are rushed, and approval done largely on a partisan and predictable basis. 
The historical and institutional role of MPs in poverty reduction activities is also significant.. Traditionally, the institutional role of MPs has been viewed largely as that of attracting development projects and programs to constituents, thereby helping to reduce poverty. However the passage of time and the evolution of constitutional developments in Ghana have rendered this institutional role anachronistic. Currently, MPs are expected to play largely legislative roles, leaving the District Assemblies to take care of local development. But the historical legacy of a "pork barrel" institutional role of MPs continues to linger. Constituents still expect parliamentarians to bring development to their doorsteps and MPs into lobby for development projects for their constituents. To meet this expectation, the MPs in 2004 lobbied and got control over the disbursement of a portion of the DACF for development projects in their constituencies. Under the terms of the current arrangements, MPs are allocated up to $5 \%$ of the DACF for poverty-reduction projects in their constituencies.

Parliamentarians also tend to play both advocacy and partisan roles. MPs are ex-officio members of the District Assemblies. Invariably they have a representational role in matters affecting poverty reduction as well as the responsibility to articulate poverty concerns in Parliament.

Since the introduction and disbursement of the MPsCF, there has been very little empirical inquiry into the internal control mechanisms for ensuring effective management and utilization of the fund. Neither the DACF secretariat nor Parliament has ever initiated a review of the fund management system and the challenges confronting its utilisation after six years of its introduction. Public governance institutions such as the Serious Fraud Office, Commission for Human Rights and Administrative, Public Accounts Committee and the Auditor General have not undertaken any rigorous audit into procedures for disbursement of the fund and its implications for accountability, good governance and poverty reduction. Civil society organisations including the vociferous media have been quiet on problems confronting the management and utilization of the MPsCF.

This current silence has left many Ghanaian researchers and accountability activists conjecturing about the actual status of the MPsCF and the responsiveness of local governments to the use of scarce public resources. This study focuses on the extent to which internal control systems within LGAs have impacted the management and utilization of the MPsCF.

\section{Study objectives}

The overall objective of this project is to undertake a comprehensive review and assessment of the systems, processes and management of the disbursement and utilization of the MP's $5 \%$ share of the DACF.

The specific objectives of the study are to:

- Determine the key stakeholders and their respective roles in monitoring the disbursement and utilization of the MPsCF 
- Review the efficacy of the monitoring of the disbursement and utilization of the MPsCF

- Find out the key issues hindering the utilization and disbursement of the MPsCF

\section{Overview of local government finance in Ghana}

\section{Source of local government finance}

Finance is the 'lifeblood' of decentralisation. However, it has remained a major problem for decentralisation in Ghana (Ayee 2006). In practical terms, Prud'homme (1989) argues that subnational governments generate about $20 \%$ of total government revenues while they spend about $30 \%$. The difference of $10 \%$ is made up of Central Government transfers. Thus, revenues to local governments consist of internally-generated revenues and Central Government transfers.

As noted earlier, the 1992 Constitution requires that $7.5 \%$ of the total revenue of Ghana be transferred to local governments based on an annually agreed formula by the legislature. The Internally

Generated Funds (IGFs) include rates and fees, rents, fines and licences, investments and income from commercial activities (Table 1). However, local governments in Ghana still rely heavily on Central Government transfers mainly because of capacity challenges in internal revenue mobilisation, mismanagement and corruption.

Table 1: Composition of Metropolitan, Municipal and District Assemblies' funding sources

\begin{tabular}{|l|c|c|}
\hline \multicolumn{1}{|c|}{ Sources } & Percentage & (\%) \\
\hline Internally Generated Funds (IGF) & 18 & \\
\hline Rates & & 4 \\
\hline Lands (e.g. Royalties) & & 2 \\
\hline Fees and fines & & 6 \\
\hline Licenses & & 3 \\
\hline Rent & & 1 \\
\hline Investment income & & 1 \\
\hline Miscellaneous & 82 & 1 \\
\hline Total grants given by the central government & & \\
\hline $\begin{array}{l}\text { Salaries/Highly Indebted Poor Country } \\
\text { (HIPC)/Donor Support/Other Transfers }\end{array}$ & 45 \\
\hline DACF & & 37 \\
\hline Total revenues & 100 & \\
\hline
\end{tabular}

Source: Decentralisation Secretariat, MoLG, Rural Development and Environment, 2006

\section{Financial accountability in LGAs}

Financial accountability at the local level has two dimensions, internal and external (Ayee 2006).

Internal accountability refers to accountability within local governments, for example the function and activities within District Assemblies. External accountability refers to local government accountability to a higher level of government, whether state, federal or central government. External accountability in Ghana is manifest in Central government control over local government activities. 
Central Government controls local government financial activities in Ghana through the approval of all financial estimates, except where unforeseen expenditure becomes necessary or costs have increased during the year. Even under such circumstances, the local authority may submit a supplementary estimate to the Minister for his approval. In addition, all loans and rates raised by a local authority must also be approved by the central government. Central government also has the power to control the award of contracts by local authorities.

Above all, at the end of the financial year Annual Accounts are prepared, showing actual revenue and expenditure, and are subject to audit. If the auditor detects any improper, unauthorised or unlawful expenditure, he may impose a surcharge on the person or persons responsible. This means that the person on whom the surcharge is imposed must refund to the local authority out of his or their own pocket the sum of money surcharged.

Local governments are also required to be accountable to the community, Parliament and government for their activities through Assembly members and The Auditor-General e.g. on health, water and sanitation among others. In particular, Article 187(2) of the 1992 Constitution enjoins the AuditorGeneral to audit and report on all the public accounts of Ghana and of all public agencies, including local government administrations.

\section{Internal control mechanisms in managing the DACF}

In addition, the internal control mechanism includes constitutional, legal and administrative procedures designed to ensure that expenses incurred are authorised and in line with regulations that guide spending revenue collection and proper reporting on revenue and expenditure, in order to promote accountability in managing scarce funds.

In Ghana, the District Chief Executive (LGCE) acts as a link between the officials, MPs, and the local communities and is supposed to be the driver of internal accountability in the District Assembly. Each District Assembly is expected to have a financial committee and the LGCE is generally accountable to the government, Assembly Members and the local communities. Article 120 (1) of Act 462, stipulates that 'Every District Assembly shall have an Internal Audit Unit' with its head being 'responsible to the Assembly in the performance of his duties'.

Similarly, Article 90 of the Local Government Act, 1993 (462) also provides that a District Assembly shall

Keep proper accounts and records, and shall prepare immediately after the end of each financial year a statement of its accounts in such a form as the Auditor-General may direct. 
The Local Government Financial Administration Act 2003 (Act 564) also provides an internal mechanism which checks the district revenue and expenditure, alongside the central government treasury of the Controller and Accountant General's Department.

Both the Financial Memorandum (FM) and Act 462 provide the framework within which local governments are to operate. While Act 462 seeks to provide general direction in terms of policy, the Financial Memorandum provides the control mechanisms of revenue and expenditure.

The Financial Memoranda (FM) for District Assemblies, 2004 spells out the monthly, quarterly and annual duties of the Finance and Administration Sub-committee of the Assembly which among other duties is to ensure that account books are up to date, and that cash and bank balances are not excessive in relation to investment. A key strength of the FM is that it ensures that Assemblies operate with a balanced budget and the District Finance Officer has powers to ensure that all payments authorized are within budget.

In addition to all these, the passage in 2003 of the Internal Audit Act, 658, and the Procurement Act, Act 663 are important legislative instruments at promoting financial accountability within the DAs. These internal and external mechanisms provide quite a good framework for promoting accountability and sound financial management in the District Assemblies.

\section{Key issues in DACF administration in Ghana}

Also important and closely related to the political control of the DACF, is the nature and quantum of mandatory deductions made on the DACF before disbursements are made to LGAs. As explained by Arthur (2012), even though the economic regulation of LGAs was intended to operate in a positive way, to prevent the local authorities from balance of payment problems, and from creating national inflation, regulatory power has been abused by the centre. Mawhood, (1993) also confirms that economic control of fiscal decentralisation by the Central government enables it to set high mandatory deductions from the DACF. In Ghana's case, as much as $49 \%$ of the allocated DACF is deducted for government priority activities even before the fund is disbursed to LGAs (see DACF Annual Guidelines 2003 - 2007 from the Ministry of Local Government and Rural Development). Consequently, LGAs have no control on almost half of their DACFs.

\section{Tensions between MPs and LGCEs}

Utilization of the DACF in Ghana has been plagued by several challenges including delays in disbursement of the fund (Owusu 2008) and political tensions between traditional authorities, government appointees and elected officials in the LGA. Arthur (2012) reports strong tensions between LGCEs (appointed by the president to represent his interests), the MPs (the popular elected representatives) and the traditional rulers (the custodian of the customs and sovereignty of the local 
people). All three groups draw on various sections of the 1992 Constitution and on other subsidiary legislation to support their claim to partake in deciding how the DACF is used. Specifically, Article 267 of the 1992 Constitution and section 5 of the Local Government Act 462 supports the legitimacy of traditional rulers in LGA activities, while Article 243 of the 1992 Constitution and Section 20 of the Local Government Act 1993, Act 462 support the role of both elected and appointed officers in the LGA.

Azeem (2003) and Boachie-Danquah (2004) suggest that the tensions especially between MPs and LGCEs have been the greatest challenge to transparency, efficiency and accountability in use of the DACF in Ghana. Though tensions may arise between LGCEs and MPs over spending from the DACF Ayee (1999), Ahwoi (2010), and Antwi-Boasiako (2010) believe that such tensions are mostly motivated by the self-interests of LGCEs and MPs rather than by the needs of the local people. Studies by Ahwoi (2006), Asibuo (2000), Arthur (2012), Ayee and Amponsah (2003) have illustrated cases where LGCEs with aspirations of contesting as MPs have siphoned off parts of the DACF to fund their campaigns. Debrah (2009) reports of deliberate delays, misappropriation, misapplication and under-spending of the DACF by LGCEs in order to stagnate development and discredit the MPs before an election. Ahwoi (2010) avers that such conflicts are rife when the LGCEs and MPs are from different political parties, while Arthur (2012) shares that conflicts revolving round the use of the DACF are also common even if both LGCE and MP come from the same political party.

\section{MPs share of the DACF}

It is recognized across literature that the underlying reason for the creation of the MPsCF was to enable MPs undertake development projects to win favour from electorates as a way of securing their seats in Parliament (Boachie Danquah, 2001; Ahwoi 2012; Arthur, 2012, Debrah 2009). Nyendu (2012) argues that the MPsCF was created by MPs as a way of addressing the political threats to their seats by LGCEs confirmed by Ahwoi, the then Minister for Local Government in Ghana. According to Ahwoi (2012), the decision to allocate part of the DACF to MPs was as a result of demands from MPs for some form of financial assistance to undertake development projects:

The leaders of both the majority and minority in parliament came to us and told us bluntly that considering the way the LGCEs were bluffing with the DACF, if we don't give MPs their share, they won't approve the formula (for the sharing of the fund) when it comes before parliament.

Kunbour (2012) suggests that the creation of the MPsCF was based on the increasing realisation in Ghana that, even though MPs are legislators, they are expected to provide public goods and services to constituents and such expectations require funding which must come from the state rather than the MPs personal funds. Similarly, Osei-Akoto et al (2007) argues that the success or otherwise of an MP in Ghana is assessed by the amount of projects during their tenure rather than by their legislative roles. 
However, deriving from the Local Government Act of 1993, funding for projects within the LGA (mainly the DACF) is controlled by the LGCE which puts LGCEs in the limelight as the ones who are overtly seen as providing goods such as KVIP toilets, roads, renovating schools etc., Thus, MPs are forced to undertake development projects from their personal funds for fear of being unseated because they were not seen undertaking any project, or honouring the promises of development made during election campaigns. Even when MPs have advocated and lobbied for particular projects in their constituencies, their efforts are not visible and credit for the project claimed by the LGCEs Thomi (2000). The issue is further exacerbated in instances where the LGCE intends to contest as an MP in subsequent elections when DACF projects are claimed as personal success stories, thereby Arthur (2012) and Nyendu (2012) concludes that the MPsCF was born because of the conduct of some LGCEs who were believed to be undermining the 'authority' of MPs through the 'personalization' of the projects completed with the DACF.

Although the practice has continued till date, Ahwoi (2010), CDD (2005) and others have maintained the illegitimacy of the MPSCF because it was based an agreement between parliamentarians rather than legislation. Indeed the lack of legislative support has been the major basis for the call to abolish the MPsCF. Quite apart from that, Mensah and Kendie (2008) argues that the MPsCF has led to duplication and politicisation of projects and programs in the LGA. Nyendu (2012) asserts that instead of carrying out development projects, some MPs hoard their share of the DACF for use in campaigning for subsequent elections. Further, Debrah (2009) believes that the MPsCF also introduces a new twist in the power struggle between MPs and LGCEs with strong disagreements by both parties on the timing, schedule, use and accountability of the MPsCF and the DACF.

\section{Methods}

The study was funded by the University of Ghana's Business School and was aimed at unearthing relevant information on the utilization and disbursement of the DACF which could be used by postgraduate students of Public Administration and local government in the University of Ghana, the Institute of Local Government Studies (ILGS), and by Local Government Officers.

The study relied in on qualitative methods used here for purposes of adopting an interpretive approach for an in depth analysis and understanding of the key issues under study. This technique was very useful because of its substantial flexibility in allowing the study to take place within the ordinary places of work of the persons involved in the study.

The main technique for data collection was key informant interviews using semi-structured questions. The interviews targeted key informants from selected LGAs in Ghana, MPs, the Audit Service, and the DACF. The instrument used for data collection was anonymous and solicited data on disbursement, utilization, accountability and internal control mechanisms of the MPs' share of the 
DACF. In order to get respondents who were abreast with the key issues being studied, only respondents who were regular participants of the training programs on local governance organised by the ILGS were considered. With appropriate permissions, the ILGS gave the research team a list of 38 persons who they considered regular participants in their training programs. Though initial contacts were made with all 38 persons on the list, only 25 were willing and available to participate in the study.

Interviews were conducted at the place of work of respondents between November 2011 and February 2012. In all, the 25 interviewees were from the Ghana Audit service, the Office of the Administrator of DACF, the Parliamentary Committee on Local Government and Rural Development, and 14 Metropolitan, Municipal and District Assemblies in Ghana. Officials of the Ministry of Local Government and Rural Development (MLGRD) declined to participate in the study because they were not directly involved in administering and monitoring the DACF but rather played an oversight role on Local Government and local level development initiatives. All respondents were key officials in their respective institutions with direct exposure to the disbursement, utilization, accountability and control of the DACF. Details of the interviewees are provided in Table 2.

Table 2: Background of respondents

\begin{tabular}{|c|c|c|c|}
\hline \multicolumn{2}{|c|}{ Institution } & Position & $\begin{array}{c}\text { Number of years } \\
\text { at post }\end{array}$ \\
\hline \multirow{4}{*}{\multicolumn{2}{|c|}{ Ghana Audit Service }} & Principal Auditor & Four years \\
\hline & & Examiner of Accounts & Four years \\
\hline & & $\begin{array}{l}\text { Acting Deputy Auditor } \\
\text { General/EIDA }\end{array}$ & 18 months \\
\hline & & Director & 2 months \\
\hline \multirow{4}{*}{\multicolumn{2}{|c|}{ Office of the DACF Administrator }} & Principal Operating Officer & 10 years \\
\hline & & Principal Operating Officer & 30 years \\
\hline & & Principal Operating Officer & 10 years \\
\hline & & Head of Internal Audit & 8 years \\
\hline \multirow{14}{*}{ LGAs } & Tema Metropolitan & Finance Officer & 20 months \\
\hline & Offinso Municipal & Planning Officer & 13 years \\
\hline & Dangme West & Assistant Director & 4 years \\
\hline & Hohoe Municipal & Coordinating Director & 10 years \\
\hline & Akwapem North & Coordinating Director & 4 years \\
\hline & Offinso Municipal & Finance Officer & 4 years \\
\hline & Pru District & Accountant & 2 years \\
\hline & $\begin{array}{l}\text { Sekondi - Takoradi } \\
\text { Metropolitan }\end{array}$ & Accounts Officer & 7 years \\
\hline & Ga East Municipal & Finance Officer & 6 years \\
\hline & Akwapim North & Finance Officer & 10 years \\
\hline & Ga East Municipal & Coordinating Director & 3 years \\
\hline & West Akim & Coordinating Director & 4 years \\
\hline & Adentan Municipal & Coordinating Director & 4 years \\
\hline & South Dayi & Coordinating Director & 3 years \\
\hline \multirow{3}{*}{\multicolumn{2}{|c|}{$\begin{array}{l}\text { The Committee on Local Government and } \\
\text { Rural Development, Parliament of Ghana }\end{array}$}} & Chairman & 3 years \\
\hline & & Member & 3 years \\
\hline & & Deputy Ranking Member & 7 years \\
\hline
\end{tabular}




\section{Monitoring the MPsCF}

In explaining the essence of giving MPs a share of the District Assemblies Common Fund (DACF, respondents explained that the DACF derived its source from Article 252 of the 1992 Constitution which provides for the establishment of the fund. The same Article also provides for the allocation of not less than 5\% of total national tax revenue into the fund. The rationale for the creation of the fund, in their view, was to strengthen the financial base of the LGAs in order to ensure effective discharge of their statutory functions. The fund was also to serve as a development endowment to be used for the benefit of all Ghanaians. In line with Article 252, the DACF was established under Act 455, 1993.

However, all respondents pointed out that there was no clearly defined legislative instrument or constitutional provision backing the disbursement of a portion of the DACF to MPs. Respondents from the OAFC explained that, even though the current formula for disbursement of the DACF sets the MPsCF at 4\% for development projects in their constituencies, there is no provision in the 1992 Constitution to support this decision. This confirms the claims of illegitimacy of the MPsCF by Ahwoi (2010) and CDD (2005).

Other respondents also traced the MPsCF to demands made by MPs for some form of financial assistance under their control to undertake development projects. This was to enable the MPs satisfy some of the demands for development made on them by the members of their respective constituency in line with Kunbour (2012). It also allowed the MPs to implement their local level initiatives independently and without financial tussles with the LGCE as identified by Arthur (2012), Azeem (2003) and Boachie-Danquah (2004). Respondents also acknowledged that several years on, no legislative backing has been given to support the MPs' share of the DACF, even though the President of Ghana's announcement in his 2009 session address that a new MP's Constituency Development Fund would be set up.

Thus, there was no clearly defined instrument supporting the MPsCF. Rather, the MPsCF was practiced was a convention that began in the Mid-1990s. By extension, this implies that non-existence of legislative guidelines for the disbursement, utilization, accountability and management of the MPs' funds.

\section{Monitoring disbursement of the MPsCF}

Evidence from respondents indicates that there are two levels of disbursement for the MPsCF. Firstlevel disbursements are made by the OACF to the various LGAs and second-level disbursements by the LGAs to their mandatory and local-priority funds. For instance, LGAs are supposed to disburse $3 \%$ of their DACF allocation to enhance the economic activities of 'persons living with disabilities'. 
To monitor the first level disbursements, Section (9) of Act 455 (that establishes the DACF) requires the MLGRD in consultation with the Ministry of Finance and Economic Planning (MoFEP) to determine expenditure under the DACF (Guidelines to the LGAs). This provision enables the MLGRD to supervise LGAs expenditure. The actual disbursement of the fund is by the OACF, under Section (7) of Act 455 which mandates the Administrator to distribute the DACF monies among the LGAs in accordance with the approved formula.

Respondents identified several actors who were, in their view, responsible for monitoring the disbursement of the MPsCF (Table 3). All respondents also acknowledged that even though the disbursement was done by the OACF, MPs accessed their share of the common fund through their LGAs.

Table 3: Responsibility for monitoring disbursement of the MPs' share of the DACF

\begin{tabular}{|l|c|}
\hline Responsibility for monitoring the MPs' share of the DACF & Respondents \\
\hline LGA officials = LGCE, District Coordinating Director (DCD), District Finance \\
Officer (DFO), District Budget Officer (DBO), District Planning and Construction \\
Unit (DPCU)
\end{tabular}

Some respondents argued that in practice monitoring is done by officials of the LGAs. Respondents in this group believed that the LGAs were ultimately responsible for monitoring the disbursement of the MPsCF, to ensure the accuracy of the amounts paid to MPs, when the payment was made, and any problems arising from the disbursement. The monitoring also ensured that the disbursement process was done judiciously and to provide accurate records to reconcile the books. Additionally, the LGAs monitored the disbursement of the MPsCF because all financial inflows and outflows of the LGAs, including the MPs' funds, were subject to internal and external audit. Some respondents also explained that because the account into which the MPsCF is disbursed is strictly managed by the LGAs without the MPs being signatories, the LGAs were ultimately responsible for the disbursement of the funds. Specific officials in the LGAs involved in monitoring the disbursement of the MPs' funds were the LGCE, District Coordinating Director (DCD), District Finance Officer (DFO), District Budget Officer (DBO), and the District Planning and Construction Unit (DPCU).

A second group of respondents believed that monitoring the disbursement of the MPsCF was done by the OACF, the MLGRD and the Auditor Generals Department. In explaining their answer, they cited section 7 of Act 455 that mandates the ACF to report in writing to the Minister in charge of the MLGRD on how allocations made to LGAs (including the MPs' funds) have been utilized. Other respondents in this group thought that monitoring of the disbursement was done by MLGRD through periodic visits and assessments reports of LGAs. Respondents in this group also pointed out that the 
Auditor General's Office played an important role in the monitoring of the disbursement of the MPsCF. Through the quarterly reports and annual audits, the Auditor General's department ensured that disbursement of the MPs' funds was done in accordance with prescribed guidelines. Respondents made particular reference to the Consolidated Report of the Auditor-general on special audits into the operations of district assemblies for the period 2001-2004 which was a result of extensive monitoring utilization of the DACF and stressed on the disbursement and utilization of the MPs common fund.

A third group of respondents, all of whom were MPs, said that monitoring of the MPsCF had to be done by MPs themselves, to ensure that they received what was due, that the funds were not unnecessarily delayed, and that the funds went to the right person, etc. In line with Debrah (2009), Ahwoi (2006), Asibuo (2000), Arthur (2012), and Ayee and Amponsah (2003), the MPs believed that they had to monitor the disbursements because some LGCEs tried deliberately to delay, or underpay their share of the DACF, and to make sure the funds were not allocated to the general LGAs budget. Respondents mentioned instances where particular LGCEs 'borrowed' or used part or all the MPs' funds for other LGA activities, when the MPs could not access the funds until the LGCEs paid back the monies 'borrowed'. The MPs also monitored the disbursements to ensure any problems in the disbursements were quickly addressed, for example one respondent could not access his share of the fund because of an inconsistency between the amount due in figures and the amount in words. Some MPs claimed that they received significantly less than they were supposed to receive, and the general consensus of these respondents was that since MPs were not signatories to the accounts into which their share of the DACF is paid, they had to oversee the disbursement.

A fourth group of respondents could not clearly pinpoint any office/official charged with the disbursement of the MPsCF. These included respondents who believed that no monitoring was undertaken on the disbursements or that no officials were clearly mandated to monitor the disbursements.

The study also solicited opinions on the policies, guidelines and processes for disbursing the MPsCF. In all, respondents put across that that the policies and guidelines covering the MPsCF were found in the general policies and guidelines for the DACF. They explained that the MLGRD issued yearly guidelines to LGAs on the disbursement and utilisation of the DACF (including the MPs' funds) based on conferred powers in Section 91(1) and 10(3) of Act 462. These guidelines are based on a formula for distributing the DACF proposed annually for approval by Parliament by the ACF in accordance with Section 7a of Act 455.

Respondents from the OACF explained that according to Act 462 and Act 455, the disbursement process for the MPsCF involved transfers through two funds - the DACF and the Reserve Fund. The Reserve fund is a part of the DACF set aside for funding MPs Constituency Projects as well as meeting any emergency expenditure. It is also used by the OACF and the Regional Coordinating 
Councils (RCC) in their monitoring and supervision roles. Contrary to public perception therefore, the DACF and the MPs' funds were not distinctly separate funds. Rather, the MPsCF was part of the reserve fund component of the DACF.

Respondents explained that the reserve fund and the MPsCF were not a fixed percentage of the DACF but varied from year to year. This is in contrast to the DACF which, as per Article 252 of the 1992 Constitution, is a pool of resources (not less than 5\%) of the nationally generated revenue that has been set aside to be shared among all the LGAs. Rather, the Reserve Fund is a percentage (determined annually) of the DACF which is deducted before the formula for sharing the DACF (designed by the ACF and approved by Parliament) is applied to the remainder. Likewise, the MPsCF was determined annually and varied from year to year (Table 4).

Table 4: Components of Reserve Fund for 2009 and 2011

\begin{tabular}{|c|c|c|c|}
\hline & 2009 & 2010 & 2011 \\
\hline Reserve Fund (percentage of DACF) & $15 \%$ & $10 \%$ & $11.8 \%$ \\
\hline MPs' share of the DACF for constituency projects & $6 \%$ & $7 \%$ & $4 \%$ \\
\hline Regional Coordinating Councils & $1.5 \%$ & $1.5 \%$ & $1.5 \%$ \\
\hline Office of the Administrator of DACF & $0.5 \%$ & $0.5 \%$ & $0.3 \%$ \\
\hline Discretionary/emergency reserves held by MLGRD & $2 \%$ & & $3 \%$ \\
\hline District Development facility and sanitation programs & $5 \%$ & $0.5 \%$ & - \\
\hline Constituency monitoring and evaluation by MPs & - & - & $4 \%$ \\
\hline Cured lepers & & $0.5 \%$ & \\
\hline
\end{tabular}

Respondents also explained that certain requirements must be met by all LGAs in disbursing the MPsCF, including the creation and maintenance of accounts for all MPs in the LGA, and the submission of monthly fund reports - including cash analysis report, bank statements and reconciliation statements. In disbursing the MPsCF, LGAs are supposed to adhere strictly to the Internal Audit Agency Act of 2003 (Act 658), The Public Procurement Act of 2003 (Act 663), the Financial Administration Act of 2003 (Act 654), the Financial Administration Regulation instrument (LI 1802), the Financial Memorandum for District Assemblies and other relevant legislations.

Respondents generally agreed that the disbursement was monitored to ensure that projects being undertaken by the MP(s) were in the line with the Medium Term Development Plan of their respective LGAs. Thus, even though the funds are intended for projects of the MPs' choice, projects must fall within the LGAs priority areas based on its Medium Term Development Plan. 


\section{Monitoring use of the MPsCF}

The study also sought information on how the use of the MPsCF was monitored, as summarised in Table 5.

Table 5: Responsibility for monitoring use of the MPs' share of the DACF

\begin{tabular}{|l|c|}
\hline Responses & No \\
\hline LGA - LGCE, DCD, DFO, DBO, District Assembly, Internal Audit Unit (IAU), Heads of & 10 \\
Department, DPCU, District Procurement Board & \\
\hline Office of the Administrator of DACF, MLGRD, GAS, RCC, MoF, CAGD & 6 \\
\hline MP - self monitoring & 3 \\
\hline All Stakeholders - Community, LGAs, CAGD, GAS, RCC, Internal and external & 6 \\
Auditors, MLGRD, Office of the Administrator of DACF, etc & \\
\hline TOTAL & $\mathbf{2 5}$ \\
\hline
\end{tabular}

As shown in Table 5, 10 respondents believed that the monitoring of the use of the MPsCF was done internally by the LGAs. Respondents in this group thought that since the fund was paid into and disbursed from an account managed by officials of the LGAs, the officials of the LGAs had the duty of monitoring use of the funds, or thought that officials of the LGAs were accountable to the Office of the DACF and auditors for all funds including the MPs' funds.

Respondents in this group also explained that LGAs were responsible for monitoring use of the MPsCF based on the MLGRDs Operational Manual for the Implementation and Administration of the District Development Facility (DDF), which requires all LGAs to use disbursements in accordance with Government of Ghana (GoG) procedures. The manual also required LGAs to plan, implement and account for funds in accordance with both the GoG's planning, budgeting and financial management systems and with the Financial Administration Act. Another reason given for LGAs involvement in monitoring was to ensure that the MPsCF were being used in line with the Medium Term Development Plan of the LGA.

These respondents also suggested that monitoring the use of the MPs' funds was done by all those persons and departments in the LGAs who played a role handling the DACF. They mentioned the LGCE, DCD, DFO, DBO, the PM and the Assembly members, the Internal Audit Unit, the DPCU, and the District Procurement Board as key actors in the monitoring.

A second group of six respondents thought that monitoring the utilization of the DACF was done by external institutions, identifying the OACF, the MLGRD, the Ghana Audit Service and the RCC as being the main actors. One respondent in this group explained that, based on Section 9 of Act 455, guidelines for using the funds were provided by the MLGRD in consultation with the MoFEP. Quite apart from providing a guide to disbursing the funds, that section of the Act is also aimed at equipping the MLGRD to exercise its supervisory responsibility over the LGAs expenditure. 
One respondent in this group explained that monitoring the use of the MPsCF was done also by OACF, to help the ACF prepare audited Accounts and an Operational Report for Parliament in accordance with Act 455; this was also confirmed by a respondent from the OACF. As the Administrator relied on the monthly expenditure returns of the LGAs to prepare his reports, he had to monitor the use of the DACF and the MPsCF.

Also of importance were opinions that monitoring was done by the RCCs. Respondents explained that the guidelines for the use of the DACF clearly suggested that the RCC was supposed to do monitoring, coordinating and evaluation of activities of LGAs. One respondent further claimed that:

The RCC is even given part of the reserve fund every year to do monitoring and evaluation of the $D A C F$ and its related funds.

A crosscheck with the DACF utilization guidelines for 2009, 2010, and 2011 confirmed this, and showed that for the relevant years the RCCs were given $1.5 \%$ of the Reserve Fund a year to fulfil their statutory monitoring role.

The Ghana Audit Service (GAS) and the Controller and Accountant General's Department (CAGD) were other key external institution involved in monitoring the use of the MPsCF. According to respondents, these institutions received quarterly and annual reports from LGAs on how funds in the LGAs were used. They also came round periodically to conduct audits and do on-site monitoring of fund management and reporting in the LGAs. Respondents also explained that GAS and CAGD monitored the utilization of the MPs' funds as a requirement of the DDF Operational Manual of 2010. According to the manual, the GAS must perform annual operational audits of all LGA and other beneficiary agencies and also perform special audits to address problems identified through regular monitoring. The CAGD per the same document is to produce an annual consolidated financial performance report of LGAs funds, receipts and utilisation to MLGRD.

A third group of three respondents argued that the monitoring was done by MPs themselves rather than by the LGAs or any other external institution. Respondents in this group (two of whom are MPs) explained that even though the fund was for their projects in line with the LGAs' Medium Term Development Plans, they were not directly involved in the management of the fund. As one respondent said:

The funds are decided by the Administrator of common funds, then they bring it to us in parliament for approval. Afterwards, the administrator transfers the funds into an account created and managed by the LGAs. They make payments for the projects on our behalf and merely ask for a memo authorising the payments

It was therefore, in their view, imperative that the MP, in whose name and for whose project the funds were allocated, should monitor the utilization of the funds to ensure that the right payments are being made. Additionally, they believed that the MPs' function should be to ensure that the service or assignments concerned were being properly executed. The other member of this group, who was from 
the Audit Service, also said that MPs should do monitoring and supervision of the projects. This assertion was confirmed by the 2011 guidelines for disbursing and utilising the DACF which included $4 \%$ of the Reserve Fund for constituency project monitoring and evaluation by MPs.

The final group presented a case for a holistic approach to monitoring the utilization of the MPsCF. Respondents in this group explained that monitoring was done not by internal or external institutions together but involved all stakeholders of the MPs' funds. Thus each and every stakeholder had a role to play in the monitoring process. The key stakeholders they identified include all the internal and external institutions identified above. It also included the Steering Committee of the DDF and the community members.

\section{Policies and guidelines}

Respondents were also asked about policies and guidelines for the use of the MPsCF (Table 6)

Table 6:Policies and Guidelines for Using MPs' share of the DACF

\begin{tabular}{|l|c|}
\hline Responses & No \\
\hline The project selected and approved must be one that meets a critical need of the community & 10 \\
\hline The project must meet the approval of the LGCE & 6 \\
\hline The project must fall within the MTDP of the LGA & 6 \\
\hline Not sure / no guiding policy or process & 3 \\
\hline TOTAL & $\mathbf{2 5}$ \\
\hline
\end{tabular}

Even though respondents were unable to identify any policy document, 10 thought that the projects selected and funded by the MPs in their LGAs were guided by the needs of the community. As one respondent explained:

Once the money has been put under the directive of the MP no one can dictate to him what project to undertake with the money. The only issue is that he must ensure that the project addresses a need in the constituency

Thus, the only guide available to the MP in using his or her share of the DACF was making sure the project met a need in the community.

Six other respondents were also of the view that it did not matter whether the project met a need or not, but the project should meet the approval of the LGCE. They explained that usually, the account into which the MPs' funds were paid was not managed by the MP. Rather, it was managed by the LGA and payment was made out of the account only on the approval of the LGCE. So even if the project meets a need but does not meet the approval of the LGCE, it will not be funded and vice versa. Thus, MPs had to ensure that their met the approval of the LGCE. This situation, according to a respondent from the Audit Service, has been the cause of conflicts between many MPs and LGCEs, especially when they are from different political parties. As she explained

In one District we worked, an MP (who was from the opposition) chose a project that met a need of the District but did not meet the approval of the LGCE (who was from the ruling Government). The LGCE said he would not approve the project because there were other projects being undertaken by the government and he expected the MP to channel his share of the common fund to complete those projects. The MP on the other 
hand claimed that the LGCE was just being petty was afraid that the MPs project would attract recognition which would translate to votes for the opposition. Also, the LGCE wanted people to think that he (the MP) had done nothing for the constituency but the ruling government through the LGCE were the ones that were developing the constituency.

As a result, MPs' main criterion had to be to ensure that their projects met the LGCEs' approval. Other respondents in this group also explained that the LGCEs approval was paramount in guiding use of the DACF. However, most LGCEs were frustrated by the MPs with regards to their choice of projects because they (LGCEs) had aspirations of contesting the seat of the MP. Thus by denying the MP his or her funds for development, the MP would become unpopular and lose support in the constituency. Currently, MPs are advocating that they be given direct access to their share of the DACF, rather than through the LGAs, because of these problems.

Another key determinant of the utilization of the MPs' funds was the fact that it had to be in line with the priority areas raised by the MTDP of the LGA. The six respondents who shared this opinion explained that the choice of project was determined more by the MTDP than by the MP or LGCE. The MTDP encapsulates the strategic development initiatives needed by the LGAs to achieve the local level goals of the National Development Policies (NDPs) and the Millennium Development Goals (MDGs). This was confirmed by the guidelines for the utilization and disbursement of the DACF between 2009 and 2011 which points out that projects selected to be funded by the MPs using their share of the common fund must be based on the LGAs MTDP.

\section{Key findings}

The key findings of the study indicate that there is no specific legislative instrument on the nature, management and accountability of the MPs' share of the DACF. However, the procedures and principles in governing the DACF in general were applied to the MPs' funds. Inferences and processes for monitoring the MPs' funds were drawn from the:

- Internal Audit Agency Act of 2003 (Act 658)

- Public Procurement Act of 2003 (Act 663)

- Financial Administration Act of 2003 (Act 654)

- Financial Administration Regulation instrument (LI 1802)

- Financial Memorandum for District Assemblies of 2004

- Local Government Act of 1993 (Act 462), the Local Government Service Act of 2003 (Act 656)

- District Assemblies Common Fund Act of 1993 (Act 455), and the 1992 constitution of the Republic of Ghana.

However, the most authoritative documents guiding the disbursement and use of the funds were the annual DACF guidelines issued by the Office of the Administrator of the DACF and the MLGRD. 
Clearly monitoring of both the disbursement and use of the MPs' share of the DACF was shared between internal and external stakeholders. The internal actors included the Chief Executive, the coordinating Director, the Finance Officer, the Budget Officer, the Presiding Member, the Assembly Members, the Internal Audit Unit, the Planning and Construction Unit, and the Procurement Board of the LGAs. The External stakeholders included the District Development Fund's Steering Committee, community members, MPs, the MLGRD, the CAGD, the Ghana Audit Service, the RCC, the Administrator of the DACF, and Parliament's Public Accounts and Local Government and Rural Development Committees

The study also found that there were issues with regards to the disbursement and use of the funds arising from the relationship between the LGCEs and MPs. In instances where the MP and the LGCE had a good working relationship there were few hindrances. However, where there was a rift between the MPs and the LGCE, there were likely to be challenges in the funding mechanisms. Also of importance was the politicisation of the disbursement and utilization of the MPs' share of the DACF. Though this was common where the MP and the LGCE belonged to different political parties, problems also existed between LGCE and MPs of the same political party, particularly where the LGCE aspired to stand as MP in the next General Election. Sitting MPs sometimes alleged that the LGCEs were frustrating the disbursement and use of the funds to deprive them the ability to undertake development projects in their constituency, letting them fall out of favour with the electorates.

Other key issues uncovered by the study were the delays in the disbursement of the MPs' share of the DACF, the inadequacy of the fund, capacity issues of those involved in disbursing and utilizing the MPs' funds and the restrictions imposed on the MPs by the MTDP of the LGAs.

\section{Conclusions}

The MPs' share of the DACF plays an important role in local economic development in LGAs in Ghana. Despite its importance, the management of the MPs' funds is still under debate with key issues bordering on disbursement, utilization and accountability of the funds. To maximise the benefits derived from the use of the MPs' funds immediate attention must be paid to enacting legislation to govern the management of the MPs' funds and give it the needed legitimacy. Such a step will resolve the debate on the essence and quantum of deductions made on the DACF before disbursement and also spell out the respective roles, likely conditions and applicable sanctions for all parties involved in the Management of the MPsCF

Quite apart from that, serious attention must be paid to addressing the paucity of capacity within the institutions in charge of monitoring the utilization and disbursement of the fund. Other issues that need immediate attention include resolving the ensuing turf wars between LGCEs and MPs, addressing the delays in the disbursement of the Fund, and as a long term measure, enhancing the 
internal revenue generation of LGAs to reduce their continuous dependence on the DACF and in effect the Central Government.

Even though the study was limited by the sample selected, it still holds broad implications for management of the DACF and the broader subject of Local Government Finance in Ghana. The study also confirms earlier studies that point strongly to political influences in the allocation, disbursement, utilization and accountability of Local Government Funds. Further, the study lays a foundation for further exploration on the application of the Public choice theory in explaining the motivations of all key stakeholders involved in the management of the DACF and other local government resources in general

$\begin{array}{ll}\text { Abbreviations } & \\ \text { ACF } & \text { Administrator of Common Fund } \\ \text { CAGD } & \text { Controller and Accountant General's Department } \\ \text { DACF } & \text { District Assembly Common Fund } \\ \text { DBO } & \text { District Budget Officer } \\ \text { DCD } & \text { District Coordinating Director } \\ \text { DDF } & \text { District Development Facility } \\ \text { DFO } & \text { District Finance Officer } \\ \text { DPCU } & \text { District Planning and Construction Unit } \\ \text { GAS } & \text { Ghana Audit Service } \\ \text { ILGS } & \text { Institute of Local Government Studies } \\ \text { LGA } & \text { Local Government Authority } \\ \text { LGCE } & \text { Local Government Chief Executive } \\ \text { MDGs } & \text { Millennium Development Goals } \\ \text { MLGRD } & \text { Ministry of Local Government and Rural Development } \\ \text { MoFEP } & \text { Ministry of Finance and Economic Planning } \\ \text { MPSCF } & \text { Members of Parliament share of the Common Fund } \\ \text { MPs } & \text { Members of Parliament } \\ \text { MTDP } & \text { Medium Term Development Plan } \\ \text { NDP } & \text { National Development Policy } \\ \text { OACF } & \text { Office of the Administrator of Common Fund } \\ \text { PM } & \text { Presiding Member } \\ \text { RCC } & \text { Regional Coordinating Council } \\ & \end{array}$

\section{References}

Ahwoi K (2012), MPs' share of Common Fund unconstitutional :http://www.ghanamps.gov.gh/newsevents/details.php?id=983( accessed on 12 / 01/ 13)

Ahwoi, K. (2006) Participatory Governance in Ghana's Decentralisation Process and the Retrogression of Legislative Enforcement' GIMPA. Journal of Leadership, Management Administration 5(1) 9-37

Ahwoi, K. (2010) Local Government and Decentralisation in Ghana. Accra: Unimax Macmillan Ltd.

Antwi-Boasiako, K. B. (2010) Public administration: Local government and decentralisation in Ghana,Conflict? Amsterdam: Amsterdam University Press

Arthur S N A (2012) The unfinished business of decentralisation: political Accountability of local government in Ghana, A case study of the Komenda-Edina-Eguafo-Abrem (KEEA) Municipality. InauguralDissertation (zur Erlangung der Doktorwürde der Philosophischen Fakultät der Rheinischen FriedrichWilhems-Universität zu Bonn), Bonn 2012

Asibuo, S. K. (2000) Decentralisation and Capacity Building in Ghana, Africa Insight 29 (3/4), 8-15 
Ayee, J. R. A. (1999) Decentralisation and Conflict: The Case of the District Chief Executive and the Members of Parliament in Ghana Friedrich Ebert Foundation: Accra

Ayee, J. R. A. and N. Amponsah (2003) 'The District Assembly and Local Government: Reflections on the 2002 Local Elections' in N. Amponsah and K. Boafo-Arthur (eds.) Local Government in Ghana: Grassroots Participation in the 2002 Local Government Elections

Ayee, JRA (2006) Accountability for Pro-poor Local Governance in Africa. In: Millet K. Olowu, D. Cameron, R. (eds.). Local Governance and Poverty Reduction in Africa. Joint African Institute, Washington DC, pp $127-150$

Azeem, V. A. et al. (2003) Financing Decentralised Development: How Well Does the DACF Work? Accra: ISODEC

Barkan J., M. Chege (1989) Decentralising the state: district focus and the politics of reallocation in Kenya. Journal of Modern African Studies 27 (3) pp. 431-453

Boachie-Danquah (2004),A study of implementation practices of the District Assemblies Poverty Alleviation Fund in the Kpando and Ga Districts. Journal of Management Studies 19(1)

Center for Democratic Development (CDD) (2005) Decentralisation, stalled by short-term policies. Democracy Watch 6(2). ISSN: 0855-417X, A Quarterly Newsletter of the Ghana Center for Democratic Governance, Accra

Dahlberg M., E. Mörk, J. Ratts $\varnothing$, H. Ågren (2007) Using a discontinuous grant rule to identify the effect of grants on local taxes and spending Journal of Public Economics 92 (12) pp. 2320-2335

Debrah, E. (2009) Assessing the quality of accountability in Ghana's district assemblies, 1993-2008, African Journal of Political Science and International Relations 3(6) pp 278-287

.Ghana, Republic of (1993). District Assemblies Common Fund Act, (Act 455), Tema, Ghana Publishing Corporation

Ghana, Republic of (1993). Local Government Act, 1993 (Act 462), Tema Ghana Publishing Corporation.

Ghana, Republic of (2003). Financial Administration Act 2003 (Act 654) Tema, Ghana Publishing Corporation

Ghana, Republic of (2003). Internal Audit Agency Act 2003 (Act 658) Tema, Ghana Publishing Corporation

Kunbour B (2012) Politics, parliamentarians \& the public: the politics of parliaments \& constituency relations www.odi.org.uk/events/presentations/163.pdf (accessed on 21/02/13)

Mawhood P (Ed) (1993). Local government in the Third World: The experience of decentralisation in tropical Africa. Chichester, John Wiley \& Sons, $2^{\text {nd }} \mathrm{Ed}$

Mensah, J. V. and S. Kendie (2008) Decentralised Departments of State, The District Assemblies and Local Level Development in Ghana. In S. B. Kendie and P. Martens (eds.). Governance and Sustainable Development. Cape Coast: Marcel Hughes Publicity Group

Nyendu M (2012)Democratic Decentralisation in Ghana: The Need for a Policy Review Journal of Asian and African Studies 2012(47) 221

.Osei-Akoto I, Robert Darko Osei, William Quarmine, George Adayi-Nwoza Adiah (2007), Public spending at the district level In Ghana Ghana Strategy Support Program (GSSP), Background Paper No. GSSP 0008, September 2007 In collaboration with: Institute of Statistical, Social and Economic Research, (ISSER) International Food Policy Research Institute

Owusu, G. (2008), 'Mobilising Revenue for District Development: The Dilemma of Local Governments, District Assemblies, in Ghana', in Afriche e Orienti (Special Issue II 2008: Decentralising Power and Resource Control in sub-Saharan Africa) pp. 22-37

Prud'homme R. (1989), "Problemes de decentralisation" (mimeo), February 1989, paper prepared for the World Bank's Workshop on Strengthening Local Government in Sub-Saharan Africa, Bologna, Italy, March 1989.

Thomi, W. (2000) People's Perception and Evaluation of District Assemblies in W. Thomi, P. W. K. Yankson and S. Y. Zanu (eds.). A Decade of Decentralisation in Ghana - Retrospect and Prospect, EPAD Research Project/Ministry of Local Government and Rural Government, Accra 